\title{
Nascent entrepreneurship and the level of economic development
}

Sander Wennekers · André van Stel •

Roy Thurik $\cdot$ Paul Reynolds

Published online: 20 June 2007

(C) Springer Science+Business Media B.V. 2007

Erratum to: Small Bus Econ (2005) 24(3):293-309

DOI 10.1007s/11187-005-1994-8

The original version of this article unfortunately contained a mistake in the author names on the webpage.

The correct name of the second author should be: André van Stel.

The online version of the original article can be found under doi: 10.1007/s11187-005-1994-8

S. Wennekers $(\varangle) \cdot$ A. van Stel $\cdot$ R. Thurik EIM, P.O. Box 7001, 2701 AA Zoetermeer,

The Netherlands

e-mail: awe@eim.nl

A. van Stel $\cdot$ R. Thurik

Max Planck Institute for Research into Economic

Systems, Jena, Germany

R. Thurik

Erasmus University Rotterdam, Rotterdam,

The Netherlands

P. Reynolds

Florida International University, Miami, FL, USA 